\title{
Changes of Gastric Secretion after Bolus and Slow Intravenous Administration of Bombesin and Neurotensin
}

Konstantinos TSALIS, Orestis IOANNIDIS, Chrysovalantis MARIORAKIS, Panagiotis CHRISTIDIS, Lydia LOUTZIDOU, Ioannis MANTZOROS, Efstathios KOTIDIS, Manousos George PRAMATEFTAKIS, Nikolaos OUZOUNIDIS, Stamatios AGGELOPOULOS

$4^{\text {th }}$ Academic Department of Surgery, School of Medicine, Faculty of Health Sciences, Aristotle University of Thessaloniki, Greece

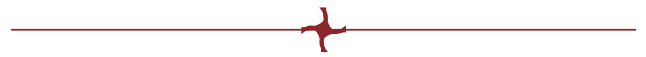

\begin{abstract}
Objective: The aim of the present study was to evaluate the changes caused by intravenous administration of regulatory peptides, bombesin (BBS) and neurotensin (NT), on gastric secretion, serum gastrin, and plasma levels of bombesin-1ike immunoreactivity (BLI) and neurotensin.

Materials and methods: Fourteen dogs underwent an upper gastrointestinal tract operation and a Pavlov pouch for the concentration of gastric fluids was formed. The experimental animals were divided into two groups. Peptides were given one month after the second operation and after fasting for 12 hours. In group $A$, the effects of BBS were studied after a rapid $1 \mu \mathrm{g} / \mathrm{kg}$ body weight dose and a slow 30' $0.5 \mu \mathrm{g} / \mathrm{kg}$ body weight dose administration intravenously. Correspondingly to group $B$ the effects of NT were studied in the same way.

Results: The rapid intravenous infusion of BBS caused a very significant increase in gastrin levels, BLI in plasma, volume and $\mathrm{HCl}$ of the gastric fluids. The same results, plus a significant decrease in gastric $\mathrm{pH}$, were observed following slow intravenous infusion of BBS. Concerning the NT, rapid administration caused a significant decrease in the volume of gastric fluids. Slow NT administration of caused a significant reduction in gastric fluid volume and in $\mathrm{HCl}$. On the contrary, $\mathrm{pH}$ was significantly increased.

Conclusion: Bombesin increases plasma gastrin levels and $\mathrm{HCl}$ secretion. Neurotensin administration causes a decrease in $\mathrm{HCl}$ secretion without affecting gastrin levels in plasma.
\end{abstract}

Keywords: gastrin, gastric fluid, gastric $\mathrm{pH}$, gastric acid, $\mathrm{HCl}$, neurotensin, bombesin.

\footnotetext{
Address for correspondence:

Orestis Ioannidis, MD, MSc, PhD, General Surgeon, Scientific Fellow

4th Academic Department of Surgery, School of Medicine, Faculty of Health Sciences, Aristotle University of Thessaloniki, Greece

Tel.: +302310814161, email: teloanakos@hotmail.com
} 


\section{INTRODUCTION}

1 large variety of biological actions on gastrointestinal tissues which affect intestinal development and adjustment, blood flow, secretion, intestinal motility, absorption of nutrients and immune response are exerted by the neuropeptides bombesin (BBS) and neurotensin (NT) (1).

More precisely, in 1971, Anastasi et al (2) isolated two peptides, BBS and alytensin, from the skin of the European frogs Bombina and Alytes. The only difference between these two peptides was regarding two out of their 14 amino acids. From then on, at least six more peptides with similar structures were isolated from the skin of these frogs. These peptides made the family of bombesin-like peptides.

Bombesin has an important mitogenic influence on grown up gastrointestinal tissue, which implies that it is of some importance when it comes to the maturation of the gastrointestinal system. By precise action on the target cells or by promoting the secretion of other relevant trophic hormones, BBS may have growth enhancing results (3). Interest upon BBS was quickly caught when it was found to be a strong stimulant of gastric secretion in dogs. At the same time, increases in secretion of hydrochloric acid $(\mathrm{HCl})$ were found to be accompanied with increases in plasma gastrin levels $(4,5)$. Later, a structurally similar peptide was isolated from the stomach and gut of pigs. Bombesin was observed to have a mammalian equivalent (6); it was named gastrin-releasing peptide (GRP) and its sequence of amino acids was determined $(7,8)$. On the other hand, BBS has only 14 amino acids. However, nine out of ten amino acids towards the carboxyl end have matching positions between those two peptides. This exact carboxyl end of BBS is the necessary part of the peptide for its biological functions (9) such as gastrin release, pancreatic enzyme secretion and smooth muscle fiber contraction. Gastrin-releasing peptide has been also discovered to have similar effects, including gastrin release stimulation, as well as even further effects at the level of the central nervous system (CNS) $(7,10)$. Bombesin-like immunoreactivity (BLI) was discovered at the level of the human gut, mammals' lungs and brain, especially the hypothalamus (11-13). Dockray et al (14) found out that $\mathrm{BLI}$ in mouse gut is located at the region of the nerves excluding the endocrine type cell. High affinity receptors for BBS were recognized inside the brain and exocrine pancreatic cells of mice as well $(15,16)$. In mammals, these findings strongly recommend the existence of a peptide or peptides like BBS. Due to their presence in brain and gut, these peptides were registered as parts of the group of brain-gut axis regulating peptides. Gastrin-releasing peptide from pigs seems to correlate with BLI. It is possible, however, that essential differences exist in the amino acid sequence between different mammals. Strong stimulation of gastric secretion in dogs with Heidenhain pouch was observed after intravenous (iv) or subcutaneous administration. Fast intravenous injection was less efficient (4).

When trying to isolate $\mathrm{P}$ substance from hypothalamic extracts of boas, Carraway and Leeman (17) discovered the presence of a substance that caused hypotension and skin vasodilatation in mice when administered intravenously. That new substance was called neurotensin and it was found to consist of 13 amino acids. Neurotensinlike immunoreactivity (NTLI) concentration in several mammal's brain is similar to that discovered in humans. High NTLI concentrations were found in the hypothalamus and lower concentrations in other parts of the brain such as the hippocampus (18-22). The higher amount of NT contained inside the body of different mammals and humans is found inside the gastrointestinal wall (21-23); most of it is contained inside some endocrinal cells of mucosa (24) called N-cells. They are numerous in the ileum, fewer in jejunum, and rare in the duodenum, and absent in the stomach, colon, and pancreas and contain specific neural enolase $(21,24)$; NTLI was observed in a few neural fibers inside the intestinal wall (25).

Except from tissues, NTLI was found in plasma of laboratory animals and humans (26). Plasma NT has a half-life lower than two minutes and is quickly decomposed in smaller peptides such as NT1-12, NT1-11 and mostly NT1-8, which have a longer half-life; NT1-8 is the most stable and has a half-life of 30 minutes (27-30). Bombesin or GRP iv administration in mice causes a fast dose-dependent increase in plasma NTLI. Increase in NTLI is not observed after BBS topical effect inside the ileum $(31,32)$. Somatostatin iv infusion causes a decrease in plasma 
NTLI basal levels in rats. In addition, somatostatin iv administration causes a significant and dose-dependent decrease in NTLI response after $\mathrm{CaCl} 2$ or BBS iv administration and endojejunum lipid administration. The somatostatin inhibitory mechanism to NT release is not known. It is also not known if either NT release is inhibited by endogenous somatostatin or somatostatin inhibitory action is clearly pharmacological. It should be noted that patients with jejuno-ileum bypass as well as those with gastrectomy show a significantly higher increase in plasma NTLI postprandially $(33,34)$.

\section{MATERIAL AND METHODS}

\section{aboratory animals}

LFourteen heathy adult mixed breed dogs weighting 16-25 kg were used for the present study. All laboratory animals were given the same food and were constantly under medical supervision. All procedures were in accordance with the criteria of the relevant clinical research ethics committee and in line with all regulations defined by the "Guide for the Care and Use of Laboratory Animals" by the National Academy of Sciences. The School of Medicine, Faculty of Health Sciences of the Aristotle University of Thessaloniki, Greece, approved the study (registration number: 404/1986-7).

\section{Pavlovs's pouch formation}

Approximately one month before conducting the main experiments, all dogs underwent a surgical procedure to create Pavlov's pouch. One day before surgery, dogs had only liquid food intake. After 12-hour fasting under general endotracheal anesthesia and sterile conditions, middle line incision from xiphoid process to the middle of hypogastrium was performed. After surgical ligature of the right gastroepiploic vessels at the borders of gastric antrum and body, a pouch $12 \mathrm{~cm}$ long and $3-4 \mathrm{~cm}$ in diameter from body to the fundus and across the greater curvature was created. The pouch cavity was fully isolated from the rest of the stomach cavity. Pouch innervation and vascularization were conserved through left gastrepiploic vessels. The peripheral pouch opening was sutured inside the lower edge of abdominal trauma and the pouch stoma sutured on the skin. Pavlov's pouch basic characteristic is its connection to the rest of the stomach with a seromuscular isthmus, containing vessels and nerves and its cavity separation from the rest of the stomach; in this way, pouch's function reflects the stomach function.

\section{Experiment protocol}

After fasting for 12 hours, each dog was placed on a Pavlov table with a loose tie around the cervical spinal region. Two venous catheters made of Teflon 18G diameter (Abbocath -T 18G X $51 \mathrm{~mm}$ ), with a three-way stopcock, were placed in the frontal limb veins. One of these catheters was used for taking blood samples and the other one for several infusions. Pavlov's pouch was catheterized with small plastic catheter (Nelaton), which was used to collect the gastric fluid.

After this preparation, the animal was left to get calm for 30' before the beginning of the experiment. Special attention was paid throughout the whole procedure to prevent any kind of external stimulation, which could influence gastric secretion. The dogs were divided into two groups (A and B) consisting in seven animals each.

Intravenous BBS effect in gastric secretion, gastrin, BLI and NT blood levels were studied in group A dogs, while IV NT effect in gastric secretion, gastrin, BLI, and NT blood levels were studied in group B dogs. Before infusion of peptides, $30 \mathrm{~mL}$ of normal saline was given iv bolus and in slow flow over 30 minutes. The results from these infusions were used as control.

Group A: Administration of BBS was done in the following ways:

1) rapid intravenous injection (bolus) in dose of $1 \mu \mathrm{g} / \mathrm{kg}$ dissolved in $30 \mathrm{~mL}$ of saline; and 2) slow iv infusion at a rate of $1 \mu \mathrm{g} / \mathrm{kg} / \mathrm{h}$ dissolved in $30 \mathrm{~mL}$ of saline. Total administration time was 30 minutes, so the total dose was $0.5 \mu \mathrm{g} / \mathrm{kg}$ body weight. A continuous infusion pump was used (B. Braun Perfusor VI).

Group B: Administration of NT was done in the following ways: 1 ) rapid iv injection (bolus) at a dose of $1 \mu \mathrm{g} / \mathrm{kg}$ body weight dissolved in $30 \mathrm{~mL}$ of saline; and 2) slow iv infusion at a rate of $1 \mu \mathrm{g} / \mathrm{kg} / \mathrm{h}$ dissolved in $30 \mathrm{~mL}$ of saline. Total administration time was 30 minutes, so the total dose was $0.5 \mu \mathrm{g} / \mathrm{kg}$ body weight. A continuous infusion pump was used (B. Braun Perfusor VI).

In all experiments, blood samples $(8 \mathrm{~mL})$ were taken at $-15,0,5,10,15,20,30,60,90$, 120 and 180 minutes relatively to initiation of peptide administration. The blood of all speci- 
mens was immediately transported into two groups of tubes which were placed in pieces of ice. In the first group of tubes, after blood clotting and centrifugation at $3000 \mathrm{rpm}$ for $10 \mathrm{mi}-$ nutes, the serum was used for gastrin measurement. EDTA was added to the tubes of the second group as an anticoagulant and $400 \mathrm{kIU}$ aprotinin/mL blood (Trasylol, Bayer, Leverkusen, West Germany). After centrifugation at $3000 \mathrm{rpm}$ for 10 minutes, plasma was separated into two groups of tubes to determine BBS and NT, respectively. Serum and plasma were maintained at $-20^{\circ} \mathrm{C}$ until the day of measurements. The gastric fluid was collected from the Pavlov's pouch at 30 minutes intervals from -30 (30 minutes before the peptide infusion) to 180 minutes post infusion.

\section{Peptides}

A) BBS: Synthetic BBS 1-14 (MB 1620) from SIGMA Chemical Company was used.

B) NT: Synthetic NT 1-13 (MB 1853.1) from SIGMA Chemical Company was used.

\section{Measurements}

a. Gastric fluid measurements: In the gastric fluid samples that were collected, the volume, $\mathrm{pH}$ and titratable acidity were determined by neutralizing the $\mathrm{HCl}$ content of the sample by adding $0.1 \mathrm{~N} \mathrm{NaOH}$ solution until it reached $\mathrm{pH} 7.0$ (PHM 62 Radiometer, Copenhagen).

b. Peptide measurement:

I. Gastrin: Serum gastrin levels were measured using a purified antibody developed in rabbits against synthetic gastrin-17 (Research Product International Corp.). The antibody was diluted to the extent that it allowed $47 \%$ binding of the added labeled antigen. The labeled antigen used was ${ }^{125}$-Gastrin-17 (New England nuclear), after diluting it with a buffer to allow a measurement rate of $4000 \mathrm{cpm}$ (impact/minute). The bound and free fraction of serum immunoreactive gastrin was separated by the use of polyethylene glycol 8000 diluted in $21 \%$ with boric acid buffer. The lower sensitivity limits of the method allow for the measurement of $10 \mathrm{pg} / \mathrm{mL}$ gastrin.

II. Bombesin: Levels of this peptide were measured by the simultaneous addition of plasma sample, rabbit purified antibody AntiBBS (Immunonuclear corp. Stillwater Mini
55082, USA), and 125I-BBS. Following overnight incubation was at $4^{\circ} \mathrm{C}$, the addition of a preprecipitated carrier, a secondary goat antirabbit antibody (GAR-PPT) and polyethylene glycol (PEG) was performed in one phase. After a 15 -minute incubation at $20-25^{\circ} \mathrm{C}$, the solution was centrifuged and separated followed by measurement of the radioactivity of the precipitate. The antibody was diluted to the extent that it allowed $53 \%$ binding of the added labeled antigen. The labeled antigen used was 125I-BBS, after diluting it with a buffer to allow a measurement rate of $5500 \mathrm{cpm}$ (impact/minute). The lower sensitivity limits of the method allow for the measurement of $8 \mathrm{pg} / \mathrm{mL}$ BBS.

III. Neurotensin: Levels of NT were measured by the simultaneous addition of plasma sample, rabbit purified antibody Anti-NT (Immunonuclear corp. Stillwater, USA), and 125I-NT. Following overnight incubation was at $4{ }^{\circ} \mathrm{C}$, the addition of a preprecipitated carrier, a secondary goat anti-rabbit antibody and polyethylene glycol (PEG) was performed in one phase. After a 30-minute incubation at $20-25^{\circ} \mathrm{C}$, the solution was centrifuged and separated, followed by measurement of the precipitate radioactivity. The buffer used for the dilutions was $0.1 \mathrm{M}$ BSA-borate-merthiolate. The final dilution of the antibody was 1:50000. The lower sensitivity limits of the method allow for the measurement of $15 \mathrm{pg} / \mathrm{mL}$ NT.

\section{Statistical analysis}

Extracted data were summarized using statistical descriptive indices of central tendency and dispersion. Data appear as mean value $+/$ - standard deviation or median and range, whenever more appropriate. Data were evaluated depending on the presentation of normal distribution or not using a normality test. Continuous values were expressed in means and standard deviations when normally distributed while in medians and interquartile ranges when not normally distributed. For the values following normal distributions, paired and unpaired t-tests were used and for values that did not follow a normal distribution, the Mann-Whitney test was used. The level of statistical significance was set at $p$ value $<0.05$ for the comparisons between the groups. All statistical analyses were performed using the IBM SPSS Statistics (V.22). $\square$ 


\section{RESULTS}

Papid intravenous administration of BBS $1 \mu \mathrm{g} / \mathrm{kg}$ body weight

Following rapid iv administration of BBS, plasma levels of bombesin-type immunoreactivity (BLI) showed a rapid and very significant increase at five minutes post-infusion $(p<0.001)$ and returned to baseline levels approximately $15 \mathrm{~min}$ utes after infusion (Figure 1). Plasma gastrin levels also showed a rapid and extremely significant biphasic increase $(p<0.001)$ five minutes after infusion and maintained at significantly high levels until 60 minutes after peptide infusion ( $\mathrm{Fi}$ gure 2). There was a significant positive correla- tion between BLI and plasma gastrin changes $(r=0.6, p<0.05)$. Plasma neurotensin levels did not show any significant changes (Figure 3 ). The gastric fluid volume increased significantly immediately after infusion $(p<0.001)$, remained significantly elevated until 90 minutes, and then returned to the baseline and markedly decreased $(p<0.05)$ at 150-180 minutes (Figure 4). The $\mathrm{pH}$ of the gastric juice gradually decreased, but not significantly, in the first 60 minutes post-infusion and then returned to previous levels ( $\mathrm{Fi}-$ gure 5). Hydrogen ion secretion increased significantly immediately after the peptide injection $(p<0.01)$ and remained significantly elevated until 90 'post infusion (Figure 6).
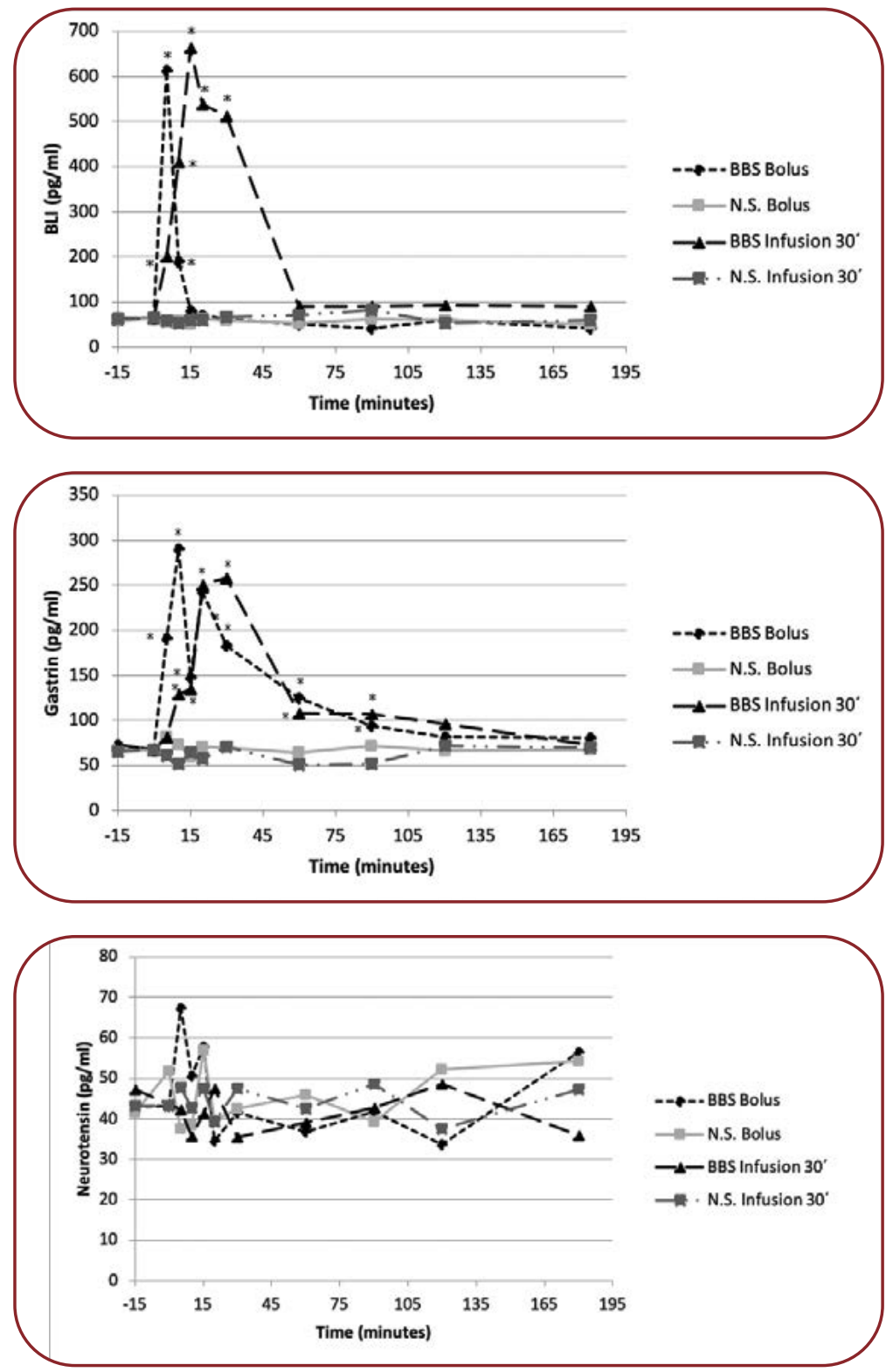

FIGURE 1. Plasma BLI (pg/mL) level changes after bolus intravenous administration of bombesin (BBS) $1 \mu \mathrm{g} / \mathrm{kg}$ and after 30 minutes of intravenous infusion of BBS at a rate of $1 \mu \mathrm{g} / \mathrm{kg} / \mathrm{h}$ compared to respective administration of normal saline (N.S.) $\left({ }^{*} \mathrm{p}<0.05\right)$

FIGURE 2. Plasma Gastrin (pg/mL) level changes after bolus intravenous administration of bombesin (BBS) $1 \mu \mathrm{g} / \mathrm{kg}$ and after 30 minutes of intravenous infusion of BBS at a rate of $1 \mu \mathrm{g} / \mathrm{kg} / \mathrm{h}$ compared to respective administration of normal saline (N.S.) $\left({ }^{*} \mathrm{p}<0.05\right)$

FIGURE 3. Plasma NT (pg/mL) level changes after bolus intravenous administration of bombesin (BBS) $1 \mu \mathrm{g} / \mathrm{kg}$ and after 30 minutes of intravenous infusion of BBS at a rate of $1 \mu \mathrm{g} / \mathrm{kg} / \mathrm{h}$ compared to respective administration of normal saline (N.S.) $\left({ }^{*} \mathrm{p}<0.05\right)$ 


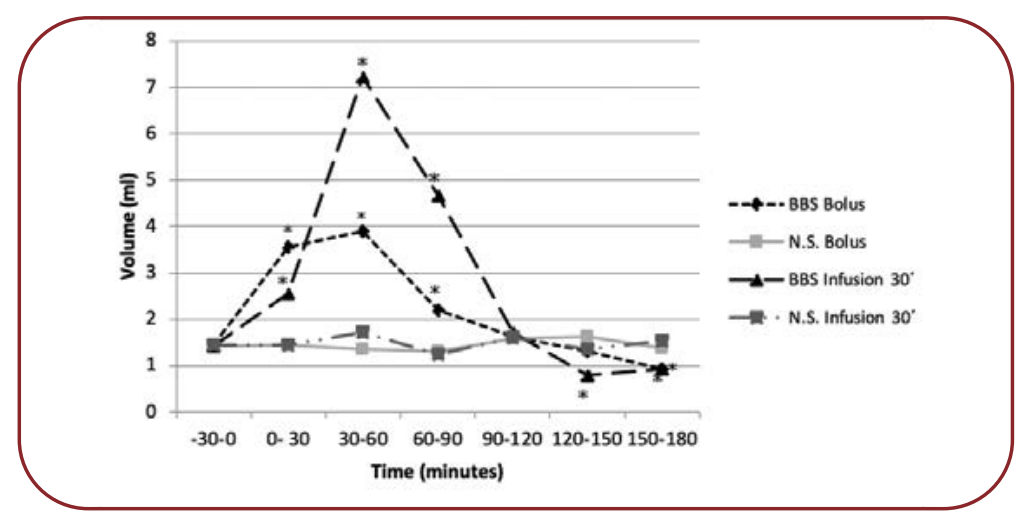

FIGURE 4. Gastric fluid volume $(\mathrm{mL})$ changes after bolus intravenous administration of bombesin (BBS) $1 \mu \mathrm{g} / \mathrm{kg}$ and after 30 minutes of intravenous infusion of BBS at a rate of $1 \mu \mathrm{g} / \mathrm{kg} / \mathrm{h}$ compared to respective administration of normal saline (N.S.) $\left({ }^{*} \mathrm{p}<0.05\right)$

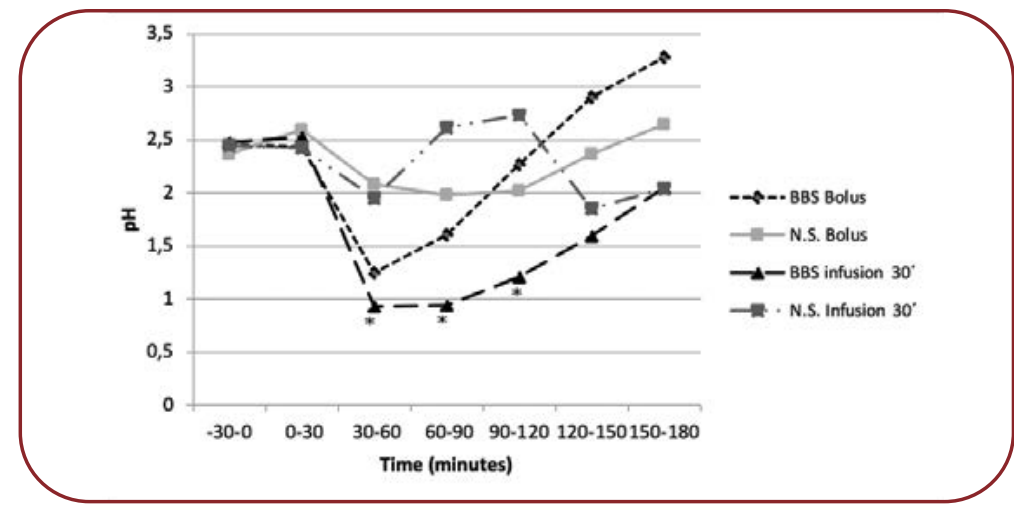

FIGURE 5. Gastric fluid $\mathrm{pH}$ changes after bolus intravenous administration of bombesin (BBS) $1 \mu \mathrm{g} / \mathrm{kg}$ and after 30 minutes of intravenous infusion of BBS at a rate of $1 \mu \mathrm{g} / \mathrm{kg} / \mathrm{h}$ compared to respective administration of normal saline (N.S.) $\left({ }^{*} \mathrm{p}<0.05\right)$

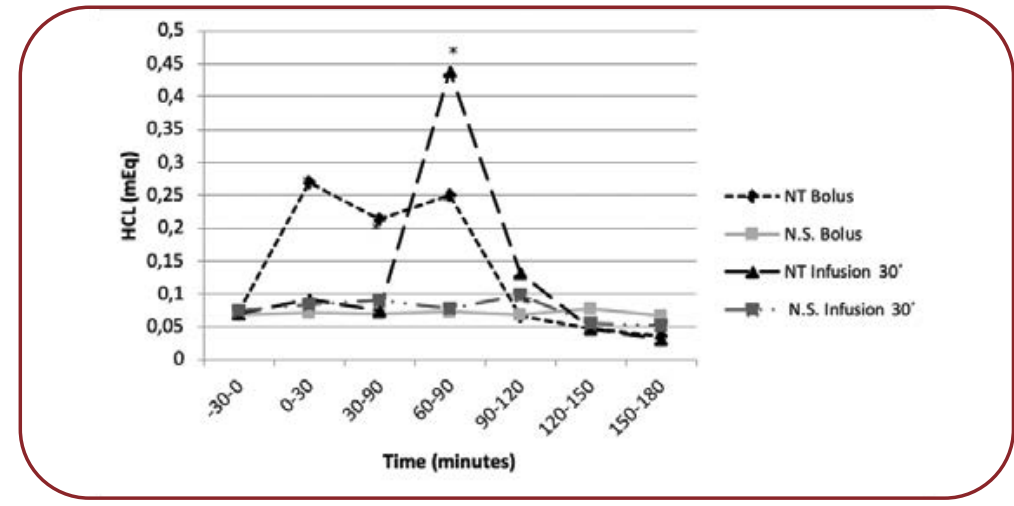

FIGURE 6. Gastric fluid HCL $(\mathrm{mEq})$ changes after bolus intravenous administration of bombesin (BBS) $1 \mu \mathrm{g} / \mathrm{kg}$ and after 30 minutes of intravenous infusion of BBS at a rate of $1 \mu \mathrm{g} / \mathrm{kg} / \mathrm{h}$ compared to respective administration of normal saline (N.S.) $\left({ }^{*} \mathrm{p}<0.05\right)$

Slow intravenous infusion of BBS $1 \mu \mathrm{g} / \mathrm{kg} / \mathrm{h}$ body weight in $\mathbf{3 0}$ minutes

Plasma BLI levels showed a progressive increase which was very significant five minutes after the start of injection $(p<0.001)$ and returned to baseline levels in 60 minutes (Figure 1). Plasma gastrin levels increased significantly from $10 \mathrm{mi}-$ nutes after the start of the infusion $(p<0.001)$ to 90 minutes, whereas plasma NT levels showed no significant change (Figures 2-3). There was a significant positive correlation between $\mathrm{BLI}$ and plasma gastrin changes $(r=0.89, p<0.001)$. Gastric fluid volume increased significantly im- mediately after the initiation of peptide infusion $(p<0.001)$ and returned to approximately initial levels over the period 90-120 minutes. Significant decrease in gastric fluid volume $(p<0.05)$ was observed during the intervals 120-150 minutes and 150-180 minutes (Figure 4). The $\mathrm{pH}$ of the gastric fluid decreased significantly $30-60 \mathrm{mi}-$ nutes after infusion $(p<0.05)$ and remained significantly low until 120 minutes after the start of the infusion (Figure 5). Hydrogen ion secretion increased significantly the 30-90-minute-interval after injection $(p<0.001)$ and gradually returned to baseline (Figure 6). 
Rapid intravenous administration of NT $1 \mu \mathrm{g} / \mathrm{kg}$ body weight

After rapid iv administration of NT, plasma NT levels as expected reached very high levels in the five-minute sample ( $p<0.001)$, but rapidly returned to pre-infusion levels in the 10-minute sample (Figure 7). Plasma gastrin and BLI levels showed no significant change (Figures 8-9), al-
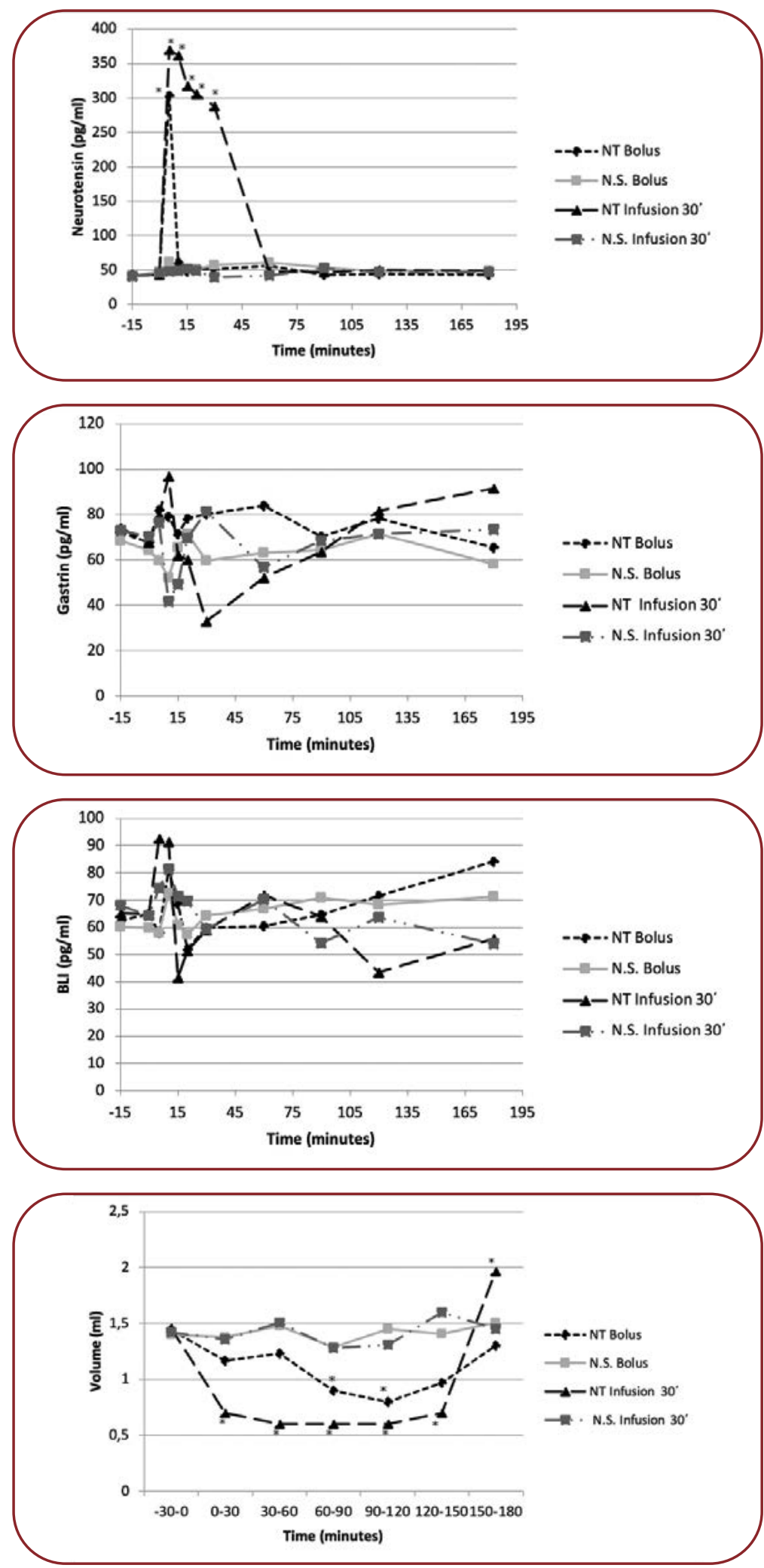

FIGURE 7. Plasma neurotensin $(\mathrm{pg} / \mathrm{mL})$ levels changes after bolus intravenous administration of neurotensin (NT) $1 \mu \mathrm{g} / \mathrm{kg}$ and after 30 minutes of intravenous infusion of NT at a rate of $1 \mu \mathrm{g} / \mathrm{kg} / \mathrm{h}$ compared to respective administration of normal saline (N.S.) $\left({ }^{*} \mathrm{p}<0.05\right)$

FI GURE 8. Plasma gastrin (pg/mL) levels changes after bolus intravenous administration of neurotensin (NT) $1 \mu \mathrm{g} / \mathrm{kg}$ and after 30 minutes of intravenous infusion of NT at a rate of $1 \mu \mathrm{g} / \mathrm{kg} / \mathrm{h}$ compared to respective administration of normal saline (N.S.) $\left({ }^{*} \mathrm{p}<0.05\right)$

FI GURE 9. Plasma BLI (pg/mL) levels changes after bolus intravenous administration of neurotensin (NT) $1 \mu \mathrm{g} / \mathrm{kg}$ body weight and after 30 minutes of intravenous infusion of $\mathrm{NT}$ at a rate of $1 \mu \mathrm{g} / \mathrm{kg} / \mathrm{h}$ compared to respective administration of normal saline (N.S.) $\left.{ }^{*} \mathrm{p}<0.05\right)$

FIGURE 10. Gastric fluid volume $(\mathrm{mL})$ changes after bolus intravenous administration of neurotensin (NT) $1 \mu \mathrm{g} / \mathrm{kg}$ body weight and after 30 minutes of intravenous infusion of $\mathrm{NT}$ at a rate of $1 \mu \mathrm{g} / \mathrm{kg} / \mathrm{h}$ compared to respective administration of normal saline (N.S.) $\left.{ }^{*} \mathrm{p}<0.05\right)$ 


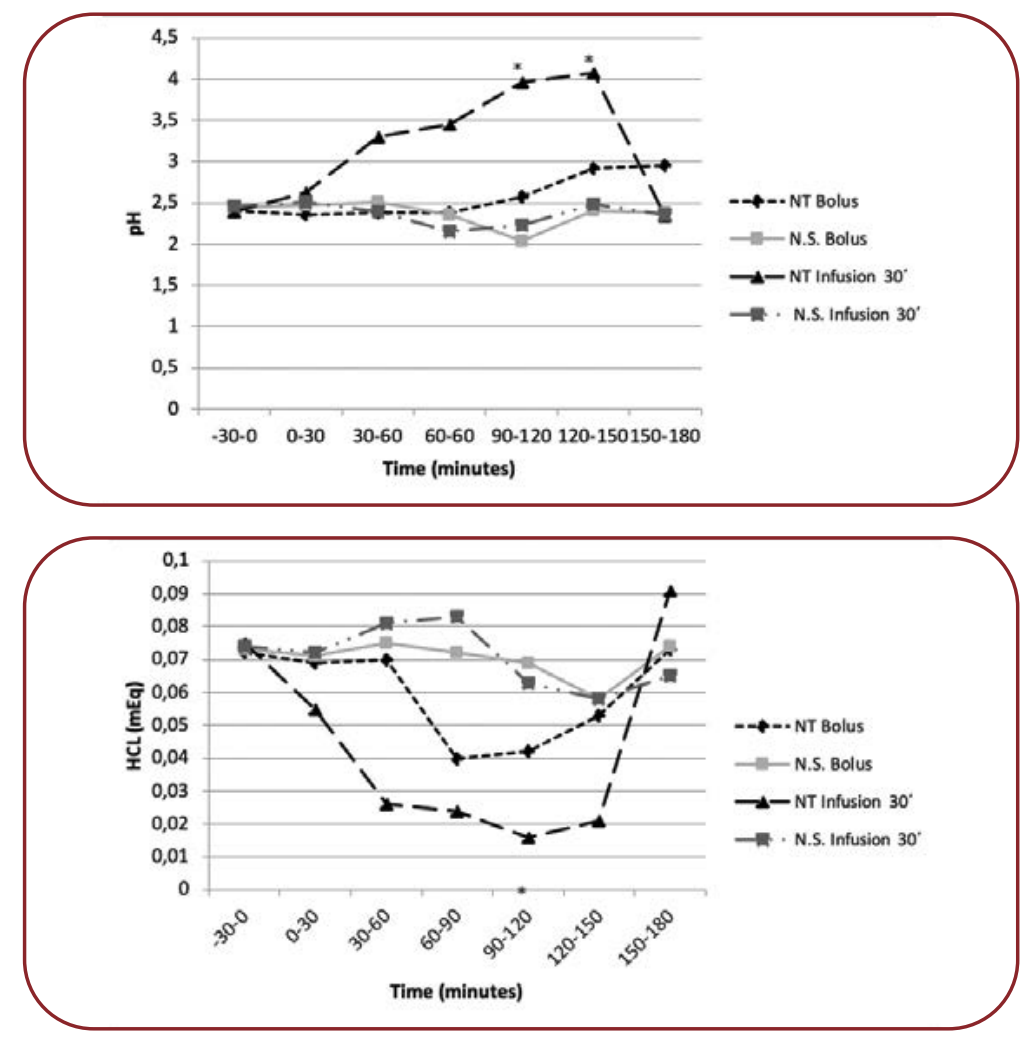

FIGURE 11. Gastric fluid $\mathrm{pH}$ changes after bolus intravenous administration of neurotensin (NT) $1 \mu \mathrm{g} / \mathrm{kg}$ body weight and after 30 minutes of intravenous infusion of NT at a rate of $1 \mu \mathrm{g} / \mathrm{kg} / \mathrm{h}$ compared to respective administration of normal saline (N.S.) $\left({ }^{*} \mathrm{p}<0.05\right)$

FIGURE 12. Gastric fluid $\mathrm{HCl}$ (mEq) changes after bolus intravenous administration of neurotensin (NT) $1 \mu \mathrm{g} / \mathrm{kg}$ and after 30 minutes of intravenous infusion of $\mathrm{NT}$ at a rate of $1 \mu \mathrm{g} / \mathrm{kg} / \mathrm{h}$ compared to respective administration of normal saline (N.S.) $\left.{ }^{*} \mathrm{p}<0.05\right)$. though there was a significant positive correlation between changes in NT and plasma gastrin $(r=0.80, p<0.01)$. Gastric fluid volume gradually decreased, and this change became statistically significant over the 60-120-minute period $(\mathrm{p}<0.05)$ (Figure 10). The $\mathrm{pH}$ of the gastric fluid did not change significantly (Figure 11). Finally, hydrogen ion secretion of the gastric fluid decreased without the change being statistically significant (Figure 12).

Slow intravenous infusion of NT $1 \mu \mathrm{g} / \mathrm{kg} / \mathrm{h}$ body weight in $\mathbf{3 0}$ minutes

Plasma NT levels showed a very significant five-minute increase after initiation of injection ( $p<0.001)$ and remained elevated to $30 \mathrm{mi}-$ nutes (end of infusion). In the next sample, 60 minutes after the start of the NT infusion, the plasma peptide value had already returned to pre-infusion levels (Figure 7). Gastrin and BLI plasma levels did not change significantly ( $\mathrm{Fi}-$ gures 8-9), despite the significant negative correlation between NT and gastrin levels $(r=-0.73$, $p<0.01)$. The volume of gastric fluid significantly decreased over time during the interval of 0-150 minutes $(p<0.01)$, whereas it increased significantly $(p<0.05)$ in the last half hour (Fig- ure 10). The gastric fluid $\mathrm{pH}$ increased progressively, which became statistically significant over the 90-150-minute period ( $p<0.05$ ) and returned to pre-infusion levels in the last sample (Figure 11). Hydrogen ion secretion of the gastric fluid showed a gradual decrease, which became statistically significant only in the 90-120-minute time interval ( $p<0.05$ ) (Figure 12).

\section{DISCUSSION}

Progressive knowledge of the physiology of the gastrointestinal tract has clearly shown that there was a great deal of interdependence between the autonomic neuron and its endocrine cells in regulating the gastric secretion. These neuro-hormonal mechanisms are separated in central and peripheral. The former is activated in the CNS and serves the known cephalic secretory phase of the gastric secretion, while the latter develops within the gastrointestinal tract wall, where local neural and hormonal mechanisms are activated during the gastric and enteric phase (35). According to the above mechanisms, the same active substances ("regulatory peptides") may be produced and released by nerve and endocrine cells and act as hormones, local regula- 
tors (paracrine action) or neurotransmitters (neurocrine action) or in all the above-mentioned ways (36). Central and peripheral administration of these peptides has been used by many to determine their regulatory role in both the endocrine and nervous systems $(4,37,38)$. The gastric acid secretion stimulation in humans, dogs and rats, are due to BBS and GRP, which enhance gastrin release, despite the fact that they also cause the production of a gastric acid secretion inhibitor. For humans and dogs, administration of either of the peptides in low or medium doses causes a parallel increase in gastric acid secretion and plasma gastrin levels. However, peptides administration at higher doses, despite the further increase in gastrin release, does not cause an increase in gastric acid secretion (39).

In the current study, BBS causing an increased $\mathrm{HCl}$ secretion seems to be due to gastrin release from the $\mathrm{G}$ cells of the antrum $(5,40)$. This assumption is concluded from the following observations that, through iv infusion, BBS causes a rapid increase in dog plasma gastrin and simultaneous stimulation of $\mathrm{HCl}$ secretion. Maximum value of gastrin is observed at approximately 30 minutes from the beginning of infusion. If the gastric fluid accumulated in the stomach is being drained out, gastrin levels are kept stable throughout the whole experiment. After stopping the infusion, gastrin levels return to baseline in less than an hour. Gastrin plasma value is proportional to the dose of BBS for a dose range of $0.05-1 \mu \mathrm{g} / \mathrm{kg} / \mathrm{h}(5,40)$; BBS stimulating secretion of gastrin and $\mathrm{HCl}$ is decreased by $85-90 \%$ after antrectomy. Mucosal antrum extraction produces the same result, although mucosal membrane regeneration steadily restores the response to BBS. Blood samples from the gastroduodenal venous 30 minutes after beginning of BBS iv infusion $(0,6 \mu \mathrm{g} / \mathrm{kg} / \mathrm{h})$ contain three times more gastrin than blood samples from the femoral artery $(5,40)$.

The review of Hirschowitz and Molina (41) in dogs with gastric fistula and Komarov eosophagostomy showed that BBS $1 \mu \mathrm{g} / \mathrm{kg} / \mathrm{h}$ iv administration caused a maximum $\mathrm{HCl}$ secretion equal to $62 \%$ of maximum $\mathrm{HCl}$ secretion induced by gastrin-17 (G-17). Higher dose of BBS caused higher increase in plasma gastrin, but $\mathrm{HCl}$ secretion decreased.

This paradox is probably because of other peptides released from BBS, including soma- tostatin from the stomach, cholocystokinine and NT from the gut and glucagon from the pancreas. Similarly, experiments in cats with gastric fistula showed that iv infusion of BBS $(0,3 \mu \mathrm{g} / \mathrm{kg} / \mathrm{h})$ causes maximum $\mathrm{HCl}$ secretion equal to $65 \%$ of maximum secretion induced by pentagastrin (42). Bombesin induced gastrin secretion results from direct effects at $\mathrm{G}$ cells, as shown by experiments (43), where human and mice isolated antrum glands without neural fibers were studied. After long lasting BBS administration in mice, a significant increase of the number of antrum $G$ cells, without a concomitant increase of size, was observed in mice (44).

BBS is the only peptide known as a strong stimulant in gastrin secretion from gastric antrum $(45,46)$. Intravenous BBS infusion $(0,6 \mu \mathrm{g} / \mathrm{kg} / \mathrm{h}$ for 30 minutes) in healthy volunteers causes significantly higher plasma gastrin increase than a protein meal. Plasma gastrin increase is rapid and reaches maximum levels 20 minutes after the onset of iv infusion. Plasma gastrin value reduces gradually and reverts to basic levels 60 minutes after the termination of infusion. Protein meal causes a smaller but more prolonged increase in gastrin. $\mathrm{HCl}$ secretion after BBS infusion reaches maximum 25 minutes after maximum gastrin value is achieved. Gastric secretion returns to basic value 90 minutes after the end of BBS infusion. Comparatively to pentagastrin $(6 \mu \mathrm{g} / \mathrm{kg} \mathrm{SC})$, BBS has a significantly smaller effect in $\mathrm{HCl}$ secretion. Atropine administration (1 mg SC) 30 minutes before the beginning of BBS infusion causes gastric secretion decrease by approximately $63 \%$, but gastrin increase does not get affected (46).

A comparative study of the iv BBS infusion effect between healthy human and patients with duodenal ulcer showed no significant difference in gastrin increase between the two groups. However, taking a protein meal caused a more significant gastrin increase in patients with duodenal ulcer. In healthy human, iv BBS infusion causes a significantly higher increase in gastrin. On the contrary, in patients with duodenal ulcer, no significant difference was observed in gastrin secretion after BBS administration or protein meal. As far as $\mathrm{HCl}$ secretion is concerned, in both groups, BBS administration (10 $\mathrm{ng} / \mathrm{kg} / \mathrm{min})$ causes smaller secretion than pentagastrin administration $(6 \mu \mathrm{g} / \mathrm{kg} \mathrm{SC})$. In patients with duodenal ulcer, BBS, as well as pentagastrin, causes 
significantly higher maximum $\mathrm{HCl}$ secretion than healthy individuals. The ratio of $\mathrm{HCl}$ secretion after BBS administration to $\mathrm{HCl}$ secretion after pentagastrin administration is the same between healthy individuals and patients with duodenal ulcer (47). Jansen and Lamers (48) showed in healthy volunteers that after simultaneous iv BBS infusion $(90 \mathrm{pmol} / \mathrm{kg} / \mathrm{h})$ and calcitonin $(0,5 \mathrm{IU} / \mathrm{kg} / \mathrm{h})$ or BBS and secretin $(1 \mathrm{CU} / \mathrm{kg} / \mathrm{h})$, plasma gastrin levels and gastric secretion are significantly lower compared to BBS infusion alone. Hence, calcitonin and secretin decrease gastrin and $\mathrm{HCl}$ increase caused by BBS iv infusion. Bombesin stimulates $G$ cells of the antrum and gastrinoma without a significant effect on gastrin-producing cells of the duodenum and jejununum (49).

In patients with previous gastrectomy and party preservation of the antrum, a higher increase in plasma gastrin is observed after iv BBS infusion than after administration of gluconic calcium (4 mg calcium $/ \mathrm{kg} / \mathrm{h}$ ) (50).

Bombesin iv infusion causes an increase in cholecystokinin (51) in lab rats and humans. Plasma NT increases after iv administration of BBS or GRP in humans $(52,53)$. The effect of BBS at glucagon, insulin and vasoactive intestinal polypeptide (VIP) levels is questioned (127) (54). Bombesin or GRP infusion in laboratory animals increases somatostatin $(55,56)$.

Peripheral administration of BBS had a stimulatory effect on gastric secretion. The effect was more profound with the slow iv infusion despite the double dose of peptide administration in the bolus infusion. This difference is probably due to the rapid removal of the peptide from the circulation after rapid iv administration because it has a short half-life (57). Our findings are in line with those of Bertaccini et al $(4,5)$. Along with the increase in gastric secretion, plasma gastrin increased both after rapid and slow iv administration of BBS and was in line with the increase observed by other authors (5, 58, 59). In cases where all gastric fluid is drained out through a gastric fistula, there is a lack of inhibitory action of $\mathrm{HCl}$ on the antrum and duodenum, and thus the plasma gastrin and the gastric secretion increase even more $(5,58,59)$. In addition to intragastric $\mathrm{pH}$, the secretory response to gastrin and $\mathrm{HCl}$ also depends on the dose of BBS for a dose range of $0.05-1 \mu \mathrm{g} / \mathrm{kg} / \mathrm{h}(5,40)$. A higher dose of BBS causes a greater increase in plasma gastrin, but the secretion of $\mathrm{HCl}$ decreases (41).
This paradoxical phenomenon may be due to the contemporary release of peptides with an inhibitory effect on gastric secretion, such as somatostatin $(55,56)$.

Bombesin increases gastric secretion after peripheral administration, apparently because it acts directly on $\mathrm{G}$ cells and increases gastrin secretion $(43,44)$. However, the fact that secretion of gastrin after dog vagotomy increases even further with BBS administration without affecting the secretory response to $\mathrm{HCl}$ means that BBS can stimulate the secretory cells through an unknown substance other than gastrin $(59,60)$.

It is very likely that the mammalian bombesin-like peptide, GRP, is released by the gastric intramuscular neurons following stimulation of the vagus nerve. This is illustrated by the fact that the electrical stimulation of the vagus nerve in an isolated mouse stomach irrigated through its vessels resulted in an increase in BLI and gastrin and a decrease in somatostatin in the portal circulation (61). Because the entire GRP found in the stomach is located in the nerves (14), it is likely that GRP-containing neurons innervate the G cells and thus directly affect their secretion of gastrin. It is also possible that the GRP released from the fundus and corpus of the stomach can reach the antrum through circulation. Gastrin release peptide, which is composed of 27 amino acids and was initially discovered in the porcine stomach (9), the gastrin-releasing peptide receptor (GRPR), its endogenous ligand, which is located only in the gastrointestinal tract, pancreas, central nervous system, and adrenal cortex influences cell proliferation, hormonal secretion, nutrition, smooth muscle contraction (62).

The view that mammalian GRP is released following vagus stimulation and induces gastrin secretion is also supported by the notion that BBS antiserum inhibits gastrin secretion induced by stimulation of the intrinsic neurons by either the electric field or 1,1-dimethyl-4-phenylpiperazine (DMPP), a substance with none agonist nicotinic effect (63). The combination of atropine and BBS antiserum causes an almost complete inhibition of gastrin secretion. Therefore, acetylcholine and GRP endogenous substances must be responsible for the secretion of gastrin after nerve stimulation.

Finally, iv administration of BBS did not affect plasma NT in our experiments, contrary to the observations of other researchers, who found an 
increase in NT following iv administration of BBS to humans (52).

Many studies of the NT structure relatively to its activity showed that C-terminus -Arg-Pro-TyrIle-Leu (64-68) is the biological reactive peptide part (69). The mechanism of NT function is not completely known. One possible mechanism is that of paracrine regulation, while another one is that of cross reaction with other substances' receptors which are the real normal mediators of these actions. The presence of NT in circulation could mean that either it has a hormonal function or it is removed from the tissue, where it has already acted paracrinically, to the blood (69). Neurotensin is found in the digestive tract and brain (70). In particular, NT is released from the neuroendocrine cells and neuronal synaptic vesicles in a calcium-dependent manner. Neurotensin is initially released as part of an inactive peptide containing 169 amino acids, and it is activated after division of this precursor complex. Neurotensin inactivation takes place extracellularly by endopeptidases, when its C-terminal sequence is proteolytically degraded (71). The two types of NT receptors (NT low- and high-affinity receptors) are distributed in the mammalian digestive tract and brain (72). They show similar structure-function in relationship to NT and recognize the same C-terminal side (71).

By the end of the $19^{\text {th }}$ century it was known that gastric secretion and mobility were inhibited when fat from a meal arrived to the small intestine (73). These data in combination with many studies in humans indicate that mostly the small intestine, and basically its peripheral part, play an inhibitory role in postprandial gastric secretion $(73,74)$. This inhibitory action was considered to be accomplished by an intestinal mucosal hormone, which Kosaka and Lim (73) named enterogastrone. From then on, many gastrointestinal hormones such as secretin, cholecystokinin (CCK) and gastric inhibitory peptide (GIP) were found to have a similar action (75).

In a recent study, Kihl et al (76) observed that fat administration inside the jejunum of healthy people or people with duodenal ulcer decreased the gastric secretion and simultaneously increased plasma NTLI. This observation is according to Rosell and Rokaeus hypothesis (73) for NT action as enterogastrone. However, fatty or mixed meal releases other peptides such as enteroglucagon, which causes a decrease of $\mathrm{HCl}$ secretion as well (77). Additionally, iv administration of fatty acid emulsion, without increasing plasma NT, decreases $\mathrm{HCl}$ secretion induced by pentagastrin, to a lower degree though than endojeunum lipid administration (78). This indicates that lipid's inhibitory action to $\mathrm{HCl}$ secretion continues even after absorption with an unknown mechanism that seems to operate independently from NT.

The effect of NT in gastric secretion was studied after iv and CNS administration. Intravenous infusion of small doses (4-30 pmol/ $/ \mathrm{kg} / \mathrm{min})$ of synthetic NT in dogs with Pavlov's pouch significantly decreases gastric secretion caused by administration of pentagastrin, test meal or insulin administration. However, it does not affect the gastric secretion induced by histamine (79). Intravenous infusion of synthetic NT in healthy volunteers and in a dose that causes plasma NTLI increase similarly to that caused by mixed meal results in the decrease in $\mathrm{HCl}$ and pepsin secretion after pentagastrin administration $(38,80)$. The inhibitory action of NT in the gastric secretion is not observed in dennervated dogs' gastric pouches (81). In experiments with healthy volunteers, Olsen et al (82) observed that synthetic NT iv infusion decreased $\mathrm{HCl}$ secretion, caused by $300 \mathrm{~mL}$ solution peptone $10 \%$ through stomach with a stable $\mathrm{pH}$ of 5.5, without any effect on gastrin secretion. These findings represent a strong indication that NT participates in the regulation of gastric secretion. Vagus mediation in NT inhibitory action upon gastric secretion was studied in patients with duodenal ulcer before and after hyperselective vagotomy. Preoperationally, iv NT infusion decreases $\mathrm{HCl}$ secretion caused by pentagastrin, while postoperationally secretion is not affected (83).

The mechanism by which NT decreases gastric secretion is not clarified yet. It is known it does not affect plasma gastrin and $\mathrm{HCl}$ secretion caused by histamine stimulation. It is also known that NT inhibitory action is dependent on vagus nerve integrity $(79,81-83)$. Data show that peptide does not act directly upon the parietal cells. Discovering the presence of nerves containing NT inside the stomach (84) suggests that the substance could act presynaptically, although a decreased sensation of parietal cells after vagotomy cannot be excluded.

Administration of NT to animals also caused alterations in the gastric secretion. Intravenous 
administration of NT reduced the gastric secretion. Rapid iv administration has been shown to have an insignificant effect, apparently because the peptide is very unstable and rapidly metabolized, as shown by our measurements. However, slow iv infusion reduced gastric secretion for 2.5 hours and increased the $\mathrm{pH}$. Our findings are consistent with those of Andersson et al $(79,81)$, who observed that intravenous administration of NT at a dose of 3-6 $\mu \mathrm{g} / \mathrm{kg} / \mathrm{h}$ reduced the gastric secretion induced by pentagastrin $1 \mu \mathrm{g} / \mathrm{kg} / \mathrm{h}$ in dogs with Pavlov's pouch. A similar decrease in gastric secretion, caused by administration of pentagastrin or normal meal, was also observed in humans after intravenous administration of NT $(0.5 \mu \mathrm{g} / \mathrm{kg} /$ body weight/h) $(38,82,83)$.

Plasma gastrin did not change significantly in our experiments after iv administration of NT. The same was observed by Olsen et al (106). The mechanism with which NT acts on the parietal cells to reduce $\mathrm{HCl}$ secretion is not known. It is certain that iv administration of NT after vagotomy does not affect gastric secretion and neither inhibits the gastric secretion induced by histamine administration $(79,81,83)$. These data, together with the finding that there are NT-containing stomach nerves (84), indicate that the peptide does not act directly on the parietal cells but before the final synapses.

\section{CONCLUSION}

ntravenous infusion of BBS causes an increase in plasma gastrin and gastric secretion. Rapid intravenous administration of the peptide is less effective. Intravenous infusion of NT decreases the gastric secretion without affecting gastrin secretion. Rapid intravenous administration of the peptide has a minimal effect.

Conflicts of interests: none declared. Financial support: none declared.

\section{$\mathbf{R}_{\text {EFerENCES }}$}

1. Assimakopoulos SF, Scopa CD, Nikolopoulou VN, Vagianos CE. Pleiotropic effects of bombesin and neurotensin on intestinal mucosa: Not just trefoil peptides. World J Gastroenterol 2008;14:3602-3603.

2. Anastasi A, Erspamer V, Bucci M. Isolation and structure of bombesin and alytesin, 2 analogous active peptides from the skin of the European amphibians Bombina and Alytes. Experientia 1971;27:166-167.

3. Günal O, Oktar BK, Ozçinar E, et al. Healing-promoting effect of bombesin treatment on chronic gastric ulcer in rats. Regul Pept 2002;106:81-88.

4. Bertaccini G, Erspamer V, Impicciatore $\mathbf{M}$. The actions of bombesin on gastric secretion of the dog and the rat. Br J Pharmacol 1973;49:437-444.

5. Bertaccini G, Erspamer V, Melchiorri P, Sopranzi N. Gastrin release by bombesin in the dog.

Br J Pharmacol 1974;52:219-225.

6. West SD, Mercer DW.

Bombesin-induced gastroprotection. Ann Surg 2005;241:227-231.

7. McDonald TJ, Nilsson G, Vagne M, et al. A gastrin releasing peptide from the porcine nonantral gastric tissue. Gut 1978;19:767-774.

8. McDonald TJ, Jörnvall H, Nilsson G, et al. Characterization of a gastrin releasing peptide from porcine nonantral gastric tissue.

Biochem Biophys Res Commun 1979;90:227-233.

9. Ramos-Álvarez I, Moreno P, Mantey SA, et al. Insights into bombesin receptors and ligands: Highlighting recent advances. Peptides 2015;72:128-144.

10. Brown M, Märki W, Rivier J. Is gastrin releasing peptide mammalian bombesin? Life Sci 1980;27:125-128.

11. Polak JM, Bloom SR, Hobbs S, et al. Distribution of a bombesin-like peptide in human gastrointestinal tract. Lancet 1976;1:1109-1110.

12. Wharton J, Polak JM, Bloom SR, et al. Bombesin-like immunoreactivity in the lung.

Nature 1978;273:769-770.

13. Brown $M$, Allen R, Villarreal J, et al. Bombesin-like activity: radioimmunologic assessment in biological tissues. Life Sci 1978;23:2721-2728.

14. Dockray GJ, Vaillant C, Walsh JH. The neuronal origin of bombesin-like immunoreactivity in the rat gastrointestinal tract.

Neuroscience 1979;4:1561-8.

15. Moody TW, Pert CB, Rivier J,
Brown MR. Bomebesin: specific binding to rat brain membranes.

Proc Natl Acad Sci USA 1978;75:5372-5376.

16. Jensen RT, Moody T, Pert $C$, et al. Interaction of bombesin and litorin with specific membrane receptors on pancreatic acinar cells. Proc Natl Acad Sci USA 1978;75:6139-6143.

17. Carraway $R$, Leeman SE. The isolation of a new hypotensive peptide, neurotensin, from bovine hypothalami. J Biol Chem 1973;248:6854-6861.

18. Polak JM, Bloom SR. The central and peripheral distribution of neurotensin. Ann N Y Acad Sci 1982;400:75-93.

19. Kahn D, Hou-Yu A, Zimmerman EA. Localization of neurotensin in the hypothalamus. Ann N Y Acad Sci 1982;400:117-131.

20. Uhl GR. Distribution of neurotensin and its receptor in the central nervous system. Ann N Y Acad Sci 1982;400:132-149.

21. Kitabgi P, Carraway R, Leeman SE. Isolation of a tridecapeptide from bovine intestinal tissue and its partial characterization as neurotensin. J Biol Chem 1976;251:7053-7058.

22. Polak JM, Sullivan SN, Bloom SR, et al. Specific localization of neurotensin to the $\mathrm{N}$ cell in human intestine by radioimmunoassay and immunocytochemistry. 
Nature 1977;270:183-184.

23. Helmstaedter V, Taugner C, Feurle GE, Forssmann WG. Localization of neurotensin-immunoreactive cells in the small intestine of man and various mammals.

Histochemistry 1977;53:35-41.

24. Sundler F, Håkanson $R$, Leander S, Uddman R. Light and electron microscopic localization of neurotensin in the gastrointestinal tract. Ann N Y Acad Sci 1982;400:94-104.

25. Schultzberg M, Hökfelt T, Nilsson G, et al. Distribution of peptide- and catecholamine-containing neurons in the gastro-intestinal tract of rat and guineapig: immunohistochemical studies with antisera to substance $P$, vasoactive intestinal polypeptide, enkephalins, somatostatin, gastrin/cholecystokinin, neurotensin and dopamine betahydroxylase. Neuroscience 1980;5:689-744.

26. Carraway R, Hammer RA, Leeman SE. Neurotensin in plasma: immunochemical and chromatographic character of acid/acetone-soluble material. Endocrinology 1980;107:400-406.

27. Leeman SE, Aronin N, Ferris C. Substance $P$ and neurotensin. Recent Prog Horm Res 1982;38:93-132.

28. Aronin N, Carraway RE, Ferris CF, et al. The stability and metabolism of intravenously administered neurotensin in the rat. Peptides 1982;3:637-642.

29. Shulkes A, Fletcher DR, Hardy KJ. Organ and plasma metabolism of neurotensin in sheep. Am J Physiol 1983;245:E457-E462.

30. Lee YC, Allen JM, Uttenthal LO, et al. The metabolism of intravenously infused neurotensin in man and its chromatographic characterization in human plasma. J Clin Endocrinol Metab 1984;59:45-50.

31. Rökaeus A, Yanaihara N, McDonald TJ. Increased concentration of neurotensinlike immunoreactivity (NTLI) in rat plasma after administration of bombesin and bombesin-related peptides (porcine and chicken gastrin-releasing peptides). Acta Physiol Scand 1982;114:605-610.

32. Rökaeus A. Increase in neurotensin-like immunoreactivity in rat plasma after administration of calcium, bombesin and fat and its inhibition by somatostatin. Acta Physiol Scand 1984;122:261-267.

33. Sagor GR, Ghatei MA, McGregor GP, et al. The influence of an intact pylorus on postprandial enteroglucagon and neurotensin release after upper gastric surgery. Br J Surg 1981;68:190-193.

34. Flaten $\mathrm{O}$, Hanssen LE, Kåresen $\mathrm{R}$, et al. Glucose-induced release of neurotensin after gastric surgery. Digestion.1982;24:94-97.

35. Konturek SJ. Cholinergic control of gastric acid secretion in man.
Scand J Gastroenterol Suppl 1982;72:1-5.

36. Polak JM, Bloom SR.

Regulatory peptides: key factors in the control of bodily functions. Br Med J (Clin Res Ed) 1983;286:1461-1466.

37. Taché $\mathbf{Y}$, Vale $\mathbf{W}$, Rivier J, Brown $\mathbf{M}$. Brain regulation of gastric secretion: influence of neuropeptides. Proc Natl Acad Sci USA 1980;77:5515-5519.

38. Blackburn AM, Fletcher DR, Bloom SR, et al. Effect of neurotensin on gastric function in man. Lancet 1980;1:987-989.

39. Unlüer EE, Denizbaşi A, Ozyazgan S, Akkan AG. Role of bombesin and cholecystokinin receptors in gastric injury induced by hemorrhagic shock in the rat. Pharmacology 2003;68:74-80.

40. Impicciatore $\mathrm{M}$, Debas $\mathrm{H}$, Walsh $\mathrm{JH}$, et al. Release of gastrin and stimulation of acid secretion by bombesin in dog. Rendic.

Gastroenterol 1974;6:99-101.

41. Hirschowitz BI, Molina E. Relation of gastric acid and pepsin secretion to serum gastrin levels in dogs given bombesin and gastrin- 17 . Am J Physiol 1983;244:G546-G551.

42. Vagne M, Gelin ML, McDonald TJ, et al. Effect of bombesin on gastric secretion and motility in the cat. Digestion 1982;24:5-13.

43. Richelsen B, Rehfeld JF, Larsson LI. Antral gland cell column: a method for studying release of gastric hormones. Am J Physiol 1983;245:G463-G469.

44. Lehy T, Accary JP, Labeille D, Dubrasquet M. Chronic administration of bombesin stimulates antral gastrin cell proliferation in the rat. Gastroenterology 1983;84:914-919.

45. Basso N, Lezoche E, Materia A, et al. Effect of bombesin on extragastric gastrin in man. Am J Dig Dis 1975;20:923-927.

46. Delle Fave G, Kohn A, de Magistris L, et al. Effect of bombesin-stimulated gastrin on gastric acid secretion in man. Life Sci 1980;27:993-999.

47. Delle Fave G, Kohn A, De Magistris L, et al. Effects of bombesin on gastrin and gastric acid secretion in patients with duodenal ulcer. Gut 1983;24:231-235.

48. Jansen JB, Lamers CB. Calcitonin and secretin inhibit bombesin-stimulated serum gastrin and gastric acid secretion in man.

Regul Pept 1981;1:415-421

49. Basso N, Lezoche E, Giri S, et al. Acid and gastrin levels after bombesin and calcium infusion in patients with incomplete antrectomy. Am J Dig Dis 1977 22:125-128.

50. Speranza V, Basso N, Lezoche E, et al. Management and long-term results in patients with two-thirds gastrectomy and stomal ulcer. Am J Surg 1981;141:105-110.
51. Erspamer V, Improta G, Melchiorri $P$, Sopranzi N. Evidence of cholecystokinin release by bombesin in the $d o g$. Br J Pharmacol 1974;52:227-232.

52. Fletcher DR, Shulkes A, Bladin PH, Hardy KJ. The effect of atropine on bombesin and gastrin releasing peptide stimulated gastrin, pancreatic polypeptide and neurotensin release in man. Regul Pept 1983;7:31-40.

53. Knigge U, Holst JJ, Knuhtsen S, et al. Gastrin-releasing peptide: pharmacokinetics and effects on gastro-entero-pancreatic hormones and gastric secretion in normal men. J Clin Endocrinol Metab 1984:59:310-315.

54. Greeley GH Jr, Thompson JC. Insulinotropic and gastrin-releasing action of gastrin-releasing peptide (GRP). Regul Pept 1984;8:97-103.

55. De Graef J, Woussen-Colle MC. Effects of sham feeding, bethanechol, and bombesin on somatostatin release in dogs. Am J Physiol 1985;248:G1-G7.

56. Bloom SR, Edwards AV,Ghatei MA. Endocrine responses to exogenous bombesin and gastrin releasing peptide in conscious calves. J Physiol 1983;344:37-48.

57. Lambert JR, Hansky J, Soveny C, Hunt $P$. Comparative effects of bombesin and porcine gastrin-releasing peptide in the dog. Digestive Diseases and Sciences1984;29:1036-1040.

58. Modlin IM, Lamers C, Walsh JH. Mechanisms of gastrin release by bombesin and food. J Surg Res 1980;28:539-546.

59. Modlin IM, Lamers C, Walsh JH, Jaffe BM. Bombesin: a vagally independent stimulator of gastrin release. Am J Surg 1981;141:98-104.

60. Hirschowitz BI, Gibson RG. Cholinergic stimulation and suppression of gastrin release in gastric fistula dogs. Am J Physiol 1978;235:E720-E725.

61. Nishi S, Seino Y, Takemura J, et al. Vagal regulation of GRP, gastric somatostatin, and gastrin secretion in vitro. Am J Physiol 1985;248:E425-E431.

62. Lau J, Rousseau E, Zhang Z, et al. Positron Emission Tomography Imaging of the Gastrin-Releasing Peptide Receptor with a Novel Bombesin Analogue. ACS Omega 2019;4:1470-1478.

63. Schubert ML, Saffouri B, Walsh JH, Makhlouf GM. Inhibition of neurally mediated gastrin secretion by bombesin antiserum. Am J Physiol 1985;248:G456-G462.

64. Heitz PU. The neuroendocrine system of the gastrointestinal tract. Pathol Res Pract 1979;165:333-348.

65. Furness JB, Costa M. Types of nerves in the enteric nervous system. Neuroscience 1980;5:1-20. 
66. Grossman MI. Neural and hormonal regulation of gastrointestinal function: an overview.

Annu Rev Physiol 1979;41:27-33.

67. Smith PH, Madson KL. Interactions between autonomic nerves and endocrine cells of the gastroenteropancreatic system. Diabetologia 1981;20 Suppl:314-324.

68. Cheng $\mathrm{H}$, Leblond CP. Origin, differentiation and renewal of the four main epithelial cell types in the mouse small intestine. V. Unitarian Theory of the origin of the four epithelial cell types. Am J Anat 1974;141:537-561.

69. Leeman SE, Carraway RE. Neurotensin: discovery, isolation, characterization, synthesis and possible physiological roles. Ann N Y Acad Sci 1982;400:1-16.

70. Ratner C, Skov LJ, Raida Z, et al. Effects of Peripheral Neurotensin on Appetite Regulation and Its Role in Gastric Bypass Surgery. Endocrinology 2016;157:3482-3492.

71. Kalafatakis K, Triantafyllou K. Contribution of neurotensin in the immune and neuroendocrine modulation of normal and abnormal enteric function. Regul Pept 2011;170:7-17.

72. Gyires K. Neuropeptides and gastric mucosal homeostasis.

Curr Top Med Chem 2004;4:63-73.

73. Rosell S, Rökaeus A. The effect of ingestion of amino acids, glucose and fat on circulating neurotensin-like immunoreactivity (NTLI) in man. Acta Physiol Scand 1979;107:263-267.

74. Clain JE, Go VL, Malagelada JR. Inhibitory role of the distal small intestine on the gastric secretory response to meals in man.

Gastroenterology 1978 ;74:704-707.

75. Brown JC, Dryburgh JR, Ross SA Dupré J. Identification and actions of gastric inhibitory polypeptide. Recent Prog Horm Res 1975;31:487-532.

76. Kihl B, Rökaeus A, Rosell S, Olbe L. Fat inhibition of gastric acid secretion in man and plasma concentrations of neurotensin-like immunoreactivity. Scand J Gastroenterol 1981;16:513-526.

77. Kirkegaard P, Moody AJ, Holst JJ, et al. Glicentin inhibits gastric acid secretion in the rat.

Nature 1982;297:156-157.

78. Petersen B, Christiansen J, Rökaeus A, Rosell S. Effect of intravenous and intrajejunal fat infusion on gastric acid secretion and plasma neurotensin-like immunoreactivity in man. Scand J Gastroenterol 1984;19:48-51.
79. Andersson S, Chang D, Folkers K, Rosell S. Inhibition of gastric acid secretion in dogs by neurotensin. Life Sci 1976;19:367-370.

80. Shulkes A, Chick P, Wong H, Walsh JH. A radioimmunoassay for neurotensin in human plasma.

Clin Chim Acta 1982;125:49-58.

81. Andersson $S$, Rosell $S$, Sjödin $L_{\text {, }}$ Folkers K. Inhibition of acid secretion from vagally innervated and denervated gastric pouches by (Gln4)-neurotensin. Scand J Gastroenterol 1980;15:253-256.

82. Olsen PS, Holst Pedersen J, Kirkegaard $\mathbf{P}$, et al. Neurotensin inhibits meal-stimulated gastric acid secretion in man.

Scand J Gastroenterol 1983;1:1073-1076.

83. Olsen PS, Pedersen JH, Kirkegaard P, et al. Neurotensin induced inhibition of gastric acid secretion in duodenal ulcer patients before and after parietal cell vagotomy. Gut 1984;25:481-484.

84. Carraway R, Leeman SE.

Characterization of

radioimmunoassayable neurotensin in the rat. Its differential distribution in the central nervous system, small intestine, and stomach.

J Biol Chem 1976;251:7045-5702. 